\title{
Women in Improving Economic Welfare (A Study on Female Gold Panners in Monterado District)
}

\author{
Deffrinica $^{1}$, Benediktha Kikky Vuspitasari ${ }^{2}$ \\ \{deffrinica@shantibhuana.ac.id ${ }^{1}$, kikky@shantibhuana.ac.id ${ }^{2}$ \} \\ Department of Management,Shanti Bhuana Institute, 1 Bukit Karmel Road, Sebopet Bengkayang, West \\ Kalimantan 79212 Indonesia $^{1}$, Department of Entrepreneurship, Shanti Bhuana Institute, 1 Bukit Karmel Road, \\ Sebopet Bengkayang, West Kalimantan 79211 Indonesia $^{2}$
}

\begin{abstract}
This study discusses the effect of gold panning on gold mining in the village of Goa Boma, whether the results of gold panning by women can increase income and affect the welfare of life. Goa Boma Village is an agricultural area where some of the people work as farmers, but not a few people who work as gold miners, especially for women (housewives) who participate in gold panning work, where gold panners are the mainstay of the Boma Cave community in village. This research was conducted in three stages. The first stage is carried out with a literature study and the second stage with a phenomenological qualitative approach and interviews with informants. Factors that affect gold panning, the environment, economic welfare and the role of women play an important role because of the low level of welfare, which demands women, especially housewives, to pan gold in the Goa Boma gold mine.
\end{abstract}

Keywords: Panning for Gold, Economic Welfare, Women, Phenomenology, Qualitative

\section{Introduction}

Indonesia is a country that has abundant natural resources with various kinds of mining materials scattered in various regions in Indonesia, such as petroleum, natural gas, gold, coal, iron ore and asphalt. One type of mining material that is quite large and available in Indonesia is gold (precious metal). Gold is a type of mining material that has a remarkably high economic value and gold is almost marketed and traded in almost all trade markets throughout the world. The investment value of gold increases every time an exceptionally large amount of gold is traded. In fact, if seen further, gold can add huge foreign exchange to gold exporting countries, including Indonesia. In ancient times gold mining has become an incredibly old form of business, managed independently by using simple tools and organized by independent community communities and developed long before this republic existed.

This shows that gold mining has become a livelihood for the community that has long been used and practiced from generation to generation so that mining has become a culture that exists in the community, even though at this time community mining is called traditional mining, community miners or even miners without permit (PETI). According to Siska Yuliati (2018), economic activities carried out by gold panners earn income that meets the needs of household members of gold panners [1]. This 
does not rule out that gold panners in Gowa Boma Village can meet the needs of their family members even though this gold panning activity is not carried out routinely.

The economic downturn of the Indonesian nation is currently being felt by all parties, including entrepreneurs and the business world. The economic downturn also resulted in an increase in the level of unemployment and the level of poverty which made people look for various ways to meet their needs.

This condition requires people to be able to provide their own job fields. This must be driven by special skills that are able to support and develop the business he is engaged in. One of them is gold mining activities or looking for gold in a traditional way. Natural resources have a buffer function for life which is particularly important for all humans on earth, in order to ensure sustainable national development. The essence of development is the development of Indonesia as a whole and community development from the use of available natural resources and the higher the level of one's income, the more positive the perception will be of the impact of traditional gold mining for social-economic changes in society. Other factors such as age, length of stay and level of education are not significantly correlated with community perceptions, this was revealed by Alfonsus (2016), while according to Ida Bagus Putu Prajna Yogi (2016), Monterado especially Gowa Boma Village is the largest mining subdistrict in West Kalimantan and shows large mining activities carried out by the community in their daily activities [2]. Gold mining in Gowa Boma Village is carried out in locations that contain gold in the traditional way or using special tools or machines called "dompeng" (gold pan), this has long been exploited by the community using modern and very simple methods and techniques known as the term panning for gold. Gold panning is carried out on the flow of water from the mining pool made by gold miner workers by filtering the sand that is located along the water flow of the mining pool, using a pan specially made of wood. Gold panning is traditionally done in general by women as a side job when not doing agricultural business activities such as going to rice fields, fields or gardens. Because using this simple method and equipment, miners do not get maximum results and even if the results are only an exceedingly small average number, it does not have a significant effect on family income.

Based on this background, the researcher wants to analyze one of the sectors of economic potential that has an influence on the social economy of society. In this case the researcher is interested in researching the mining sector, especially mining gold. Therefore, the researcher took the title of "The Effect of Gold Panning on the Level of Economic Welfare of Women in the Inland".

\section{Method}

From the aspect of type, this research is referred to as a phenomenological qualitative research. Qualitative research seeks to understand the meaning of phenomena, events and their relation to the society being studied in the context of life. The focus of this research is on women who pan gold in the village of Goa Boma who work as gold panners in gold mining to improve the economic welfare of the family so as to alleviate poverty in their household, this research will be conducted in three stages: the first stage (TP) is by using a literature study.

In the second stage (TD) observation is data collection by going directly to the field to directly observe the object under study. Observations made with a qualitative approach to phenomenology and other supporters. The observation subjects were women who panned gold in the village of Gowa Boma.

In the third stage (TT) in-depth interviews are needed in the process of obtaining information for research purposes so that the data obtained is more accurate and its existence can be ascertained. An interview is a meeting of two people to exchange information and ideas through question and answer, so that meaning can be constructed in a particular topic [3]. 


\subsection{Data Collection Technique}

The data collection technique is done by using recorded observations. The results of observing the activities of the daily gold panning women group will be written in descriptive notes and will be documented. The observation will be carried out for 6 months by monitoring all women's activities while doing their work of panning for gold in Gowa Boma Village from morning to evening.

The method of recording is also carried out at the time of observation in order to add data to make it more accurate. This method is used when there is something that can be caught by the eye and used as data.

\subsection{Data Analysis}

Data analysis in this study will use a data analysis process with Interpretative Phenomenological Analysis (AFI) or Interpretative Phenomenological Analysis as written by Smith et al (2012) [4]. AFI aims to reveal in detail how the participants interpret their personal and social world. The main target is the meaning of various experiences, events, and status that the participants have. AFI also tries to explore personal experiences and emphasizes the perception or opinion of an individual about objects or events.

The stages of Interpretative Phenomenology Analysis (AFI) are carried out as follows:

1. Read and reread

The form of this stage of activity is to write interview transcripts from audio recordings into transcripts in written form. Reading and rereading also makes it easier to assess how relationships and trust are built in the interview and then reveal parts that are rich and more detailed or contradictions and paradoxes.

2. Initial noting

This stage examines the content / content of words, sentences and language used by participants at the exploratory level. The researcher starts the activity by reading, then makes exploratory notes or general notes that can be added by reading the next one. The descriptions that the researcher develops through these preliminary notes become the core descriptions of the comments which are clearly the focus of phenomenology and remarkably close to the explicit meaning of the participants.

3. Developing any emerging themes

The process of identifying emerging themes by reorganizing participant experience data.

4. Looking for relationships between emerging themes

The researcher looks for relationships between emerging themes, which is done after the researcher has determined a set of themes in the transcript and the themes have been sorted chronologically. The relationship between these themes is developed in the form of graphics or mapping / mapping and thinking about themes that are compatible with one another.

5. Moving to other participants

Analysis stages 1- 4 were carried out for each participant. If one participant finishes and the results of the analysis are written down, the next stage moves to the next participant until all participants are finished. This step is carried out on all participant transcripts, by repeating the same process.

6. Looking for patterns between participants

The final stage is the sixth stage in this analysis, which is to look for patterns that emerge between participants. What is the relationship between participants, and how the themes found in other 
participants guide the researcher in delineating and re-labeling the themes. At this stage, a table of themes is made for one participant or group of participants

7. Credibility

Researchers will take various steps so that the credibility of this research can be maintained, namely by: member checking (i.e. asking participants to read back the results of the research), peer checking (in the form of checking the results of interviews and observations with fellow researchers) and data triangulation (i.e. checking data through other sources, namely customers and other traders).

\section{Results}

Goa Boma Village is in Monterado Subdistrict, Bengkayang Regency, West Kalimantan with a population of 165 families and on average some housewives work as farmers and some also work as gold panners.

1. Income of female gold miners / month (Table 1).

Table 1. Total Income of Female Gold Panners.

\begin{tabular}{ccccc}
\hline \multirow{2}{*}{ No } & Respondents Names & \multicolumn{2}{c}{ Income } & \multirow{2}{*}{$\begin{array}{c}\text { Number of Family } \\
\text { Member }\end{array}$} \\
\cline { 3 - 4 } & & Day/mg & IDR/day & 6 \\
\hline 1 & Respondent 1 & $200 \mathrm{mg}$ & 300,000 & 7 \\
2 & Respondent 2 & $100 \mathrm{mg}$ & 150,000 & 3 \\
3 & Respondent 3 & $100 \mathrm{mg}$ & 150,000 & 4 \\
4 & Respondent 4 & $100 \mathrm{mg}$ & 150,000 & 5 \\
5 & Respondent 5 & $200 \mathrm{mg}$ & 300,000 & 3 \\
6 & Respondent 6 & $100 \mathrm{mg}$ & 150,000 & 3 \\
7 & Respondent 7 & $100 \mathrm{mg}$ & 150,000 & 5 \\
8 & Respondent 8 & $200 \mathrm{mg}$ & 300,000 & 4 \\
9 & Respondent 9 & $200 \mathrm{mg}$ & 300,000 & 3 \\
10 & Respondent 10 & $100 \mathrm{mg}$ & 150,000 &
\end{tabular}

Table 1 depicts that the income of women gold miners can be seen based on how many milligrams of gold they can obtain from 09.00 am to $15.00 \mathrm{pm}$. In the activity of panning for gold, the hours of work have been set at 9:00 a.m. and even at 8:00 p.m. In one working day they can get 100-200 mg, if sold it gets IDR 150,000 to IDR 200,000 while the gold results obtained are not sold directly until 1 gram can reach IDR 550,000.

Based on the results of interviews with respondents as gold buyers of gold panners in the village of Goa Boma, he said that the price of gold purchased depends on the level of gold, if 1 gram of Ketapang gold is IDR 820,000, Pop gold is IDR 920,000, Cast Gold in the grade of 75\% is IDR 920,000 assuming the following calculation $920 \times 75 \%=69 /$ gram. This calculation is based on the world price and the gold purchased is clean and in the form of gold, while for low grade gold ,price is not known by the buyer respondents, only cast gold with good quality is purchased.

Based on the results of the analysis of the income of female gold panning workers, it is sufficient to contribute to the improvement of the family economy even though gold panning activities use traditional tools to get gold. The income is different from that of the gold miners who use the modern 
gold pan because these women miners can only take sand or soil from the digging hole of the former gold panners.

\section{Discussions}

\subsection{Women in Improving Family Economic Welfare}

\subsubsection{Women Increase Family Welfare}

The welfare of life is the dream of every human being. A prosperous society will not be realized if they live in poverty. Therefore, poverty must be eliminated because it is a form of welfare, describing a condition that is lacking in fulfilling economic needs. The strategy to increase the people's economic welfare is aimed at strengthening the position and role of the community's economy in the national economy.

According to the Coordinating Ministry for People's Welfare, prosperity is a condition in which their basic needs have been met. These basic needs are in the form of sufficiency and quality of food, clothing, shelter, health, education, employment, basic needs and the fulfilment of human rights and participation as well as the realization of a community of faith and piety to God Almighty.

According to Ali Khomsan, welfare can be divided into physical and mental well-being. Wellbeing that is born is usually known as economic welfare. Welfare measures are more complex than poverty. Well-being must be able to meet physical, psychological, social and spiritual needs. Welfare can be achieved if a person has access to work, income, food, education, housing, health, and others.

One measure that can be used to measure the level of welfare of a family in Indonesia is by looking at the criteria for family stages set by the BKKBN. According to the National Family Planning Coordinating Board / BKKBN (1996), the stages of a prosperous family consist of:

a. Underprivileged, a family that has not been able to meet their basic needs minimally or not fully met, such as spirituality, food, clothing, shelter, health and family planning.

b. Prosperous I, a family that has been able to meet their basic needs minimally but has not been able to meet their social psychological needs, such as the need for education, family planning, interaction in the family, interaction with the living environment and transportation.

c. Prosperous II, a family that has been able to meet their basic needs and social psychological needs but has not been able to meet development needs such as the need for saving and obtaining information.

d. Prosperous III, a family that has been able to meet basic needs, social psychology and development but has not been able to provide regular contributions to society, or has not fulfilled social concerns such as material donations and plays an active role in community activities.

e. Prosperous III plus, a family that has been able to meet basic, social psychological and development needs, and has been able to make regular contributions and play an active role in community activities or have high social awareness.

The economic status of the family is the economic capacity of a family to fulfil every need of life for all family members, so the role of the head of the household is very important in terms of improving the economic welfare of the family, it does not preclude the possibility of women also working to increase the economic welfare of the family and meet household needs. 
Gold panning women in the village of Goa Boma for the sake of getting a prosperous family life and can fulfil their daily needs working as gold panners. With daily income of IDR 150,000 to IDR 200,000 per day can meet the needs of the family per day.

\subsubsection{Women Improve Family Economy}

This research was conducted in Goa Boma Village, Monterado Subdistrict. This village as the basis of the research was determined by several reasons, including the location which is large enough for gold mining / gold panning, the residents of Goa Boma Village, most of them work as gold prospectors. This research aims to find out the role of women in improving the family economy, both directly and indirectly, women who pan gold in Goa Boma Village contribute to improving the family economy. Table 1 shows that $80 \%$ of the respondents can support their family's economy from income earned through gold panning. Furthermore, from the results of panning for gold they must be able to meet their daily needs. Thus, on average, women who pan gold try to help their families improve the family economy.

\section{Conclusion}

Based on the results of the research and discussion, it can be concluded as follows:

1. The role of women who pan gold in the family has two active roles, namely the public and domestic roles that are carried out in household activities.

2. $80 \%$ of female gold panners can support the family economy and meet the needs of family life to be prosperous.

\section{References}

[1] Yuliati, S.: Kontribusi Kesejahteraan Ekonomi Pertambangan Emas Terhadap Pendapatan Pekerja Dan Pendulang Di Nagari Lubuk Gadang Kecamatan Sangir Kabupaten Solok Selatan, J. Buana, vol. 2, no. 2, p. 669, (2018).

[2] Yogi, I. B. P. P.: Lanskap Pertambangan Penambang Cina Di Monterado, Kalimantan Barat: Pendekatan Arkeologi Sejarah. Pusat Arkeologi Bali, Forum Arkeol., vol. 29, no. 1, pp. 1-10, (2016).

[3] Sugiyono, P. D.:Quantitative, Qualitative and R \& D Research Methods. Bandung: Alfabeta Cv, (2013).

[4] Smith, J. A. and Shinebourne, P.:Interpretative phenomenological analysis. Washington, DC: American Psychological Association, (2012). 